\title{
Note
}

\section{General procedure to initialize the cyclic soil water balance by the Thornthwaite and Mather method}

\author{
Durval Dourado-Neto'; Quirijn de Jong van Lier²; Klaas Metselaar ${ }^{3}$; Klaus Reichardt ${ }^{4 *}$; \\ Donald R. Nielsen ${ }^{5}$ \\ ${ }^{1}$ USP/ESALQ - Depto. de Produção Vegetal, C.P. 09 - 13418-900 - Piracicaba, SP - Brasil. \\ ${ }^{2}$ USP/ESALQ - Depto. de Ciências Exatas. C.P. 09 - 13418-900 - Piracicaba, SP - Brasil. \\ ${ }^{3}$ WUR - Dept. of Environmental Sciences, Postbus 47 - 6700AA - Wageningen - The Netherlands. \\ ${ }^{4}$ USP/CENA, Lab. de Física do Solo, C.P. 96 - 13400-970 - Piracicaba, SP - Brasil. \\ 'UCD - Dept. of Land, Air and Water Resources - 95616 - Davis, CA - USA. \\ rCorresponding author <klaus@cena.usp.br>
}

\begin{abstract}
The original Thornthwaite and Mather method, proposed in 1955 to calculate a climatic monthly cyclic soil water balance, is frequently used as an iterative procedure due to its low input requirements and coherent estimates of water balance components. Using long term data sets to establish a characteristic water balance of a location, the initial soil water storage is generally assumed to be at field capacity at the end of the last month of the wet season, unless the climate is (semi-) arid when the soil water storage is lower than the soil water holding capacity. To close the water balance, several iterations might be necessary, which can be troublesome in many situations. For (semi-) arid climates with one dry season, Mendonça derived in 1958 an equation to quantify the soil water storage monthly at the end of the last month of the wet season, which avoids iteration procedures and closes the balance in one calculation. The cyclic daily water balance application is needed to obtain more accurate water balance output estimates. In this note, an equation to express the water storage for the case of the occurrence of more than one dry season per year is presented as a generalization of Mendonça's equation, also avoiding iteration procedures.
\end{abstract}

Key words: actual and reference evapotranspiration, deficit and excess water

\section{Critério geral para iniciar o balanço hídrico pelo método de Thornthwaite e Mather}

\begin{abstract}
RESUMO: O método original de Thornthwaite e Mather, proposto em 1955 para calcular o balanço hídrico semanal, é utilizado com freqüência devido à baixa exigência de dados de entrada e da obtenção de estimativas coerentes dos parâmetros do balanço. Como valor inicial para o início dos cálculos, geralmente assume-se que o armazenamento de água encontra-se na capacidade de campo ao fim do último mês da estação chuvosa. Ele será menor que a capacidade de campo em casos de climas áridos e semi-áridos. Para fechar o balanço, muitos ciclos iterativos podem ser necessários, o que pode ser complicado em muitas situações. Para climas áridos e semi-áridos com apenas uma estação seca, Mendonça desenvolveu em 1958 uma equação para quantificar o armazenamento no último mês da estação chuvosa, que permite fechar o balanço em um ciclo apenas. $\mathrm{O}$ balanço hídrico diário torna-se necessário para se obter estimativa de saídas mais precisas. Nessa nota, é apresentada uma rotina para expressar o armazenamento de água para o caso da ocorrência de mais de uma estação seca, uma situação que é bastante relevante quando é feito o balanço em escala diária, em regiões áridas e semi-áridas. Palavras-chave: evapotranspiração real e de referência, deficiência e excedente hídrico
\end{abstract}

\section{Introduction}

Climatologic soil water balance estimation is an important tool for edaphological characterization (Martin et al., 2008). Among the methods to estimate the soil water balance from simple soil and climate data, the method proposed by Thornthwaite and Mather (1955) is one of the most widely used. This procedure allows estimating the actual evapotranspiration, soil water deficit and excess. Therefore, it is especially useful for evaluating the effectiveness of agricultural practices (Dunne and Leopold, 1970;
Black, 1996; Silva et al., 2006; Bruno et al., 2007; Sparovek et al., 2007).

Soil water balance as estimated by the Thornthwaite and Mather (1955) method (monthly scale) can be applied for climate classification, hydrological characterization for water management, environmental studies; and agricultural planning to define land use and agricultural practices. To initiate the calculation procedure, soil water storage is assumed to be at field capacity at the end of the last month of the wet season. However, in arid and semi-arid regions this soil water storage will be lower than the soil water holding capacity. 
For (semi-) arid climates with one dry (and one wet) season, Mendonça (1958) derived an equation to quantify the soil water storage at the end of the last month of the wet season, without the need of iterations. Many authors have used the original Thornthwaite and Mather's model (Alley, 1984), while others have shown that this procedure can also be applied to smaller time scale (Eaton, 1995; Swanson, 1996), modifying the original model in an effort to improve certain components of the water balance. Steenhuis and Van Der Molen (1986) and Rushton et al. (2006) presented a study of the Thornthwaite's method at a daily scale.

The uses of a monthly scale in water balance models can, for example, lead to as much as a $25 \%$ underestimate of groundwater recharge (Rushton and Ward, 1979). The recharge estimation tends to decrease if the time scale is lower. If the accounting period is longer than ten days, Howard and Lloyd (1979) also demonstrated that large errors could occur in the water balance.

A modified Thornthwaite and Mather's model was applied by Swanson (1996) in Wisconsin. The recharge was considerably lower than needed for the successful calibration of a regional groundwater flow model (Krohelski et al., 2000). One of the main explanations for the low estimates was related to the use of a monthly scale in the water balance calculations. Thornthwaite and Mather (1957) gave a brief example of a daily application, because this is needed for more accurate water balance output estimates. They reported that their procedure could theoretically be used at a daily scale.

In this note, an equation that generalizes the approach of Mendonça (1958) is proposed to determine the initial soil water storage without making use of iterations, for locations with more than one dry and wet seasons per year, a situation which becomes especially relevant in arid and semi-arid climates.

\section{Theoretical background}

The monthly cyclic water balance (Thornthwaite and Mather, 1955)

The basic equation to estimate the actual soil water storage $(A, \mathrm{~mm})$ is (Thornthwaite and Mather, 1955) (Appendix A):

$A=A_{c} \cdot \mathrm{e}^{-\frac{L}{A_{c}}}$

where $\mathrm{L}$ is the accumulated potential water loss $(\mathrm{mm})$, defined as the accumulated sum of the difference between pluvial precipitation $(\mathrm{P}, \mathrm{mm})$ and potential evapotranspiration (ETo, mm) (equation 3) and $A_{C}$ is the soil water holding capacity $(\mathrm{mm})$ :

$A_{C}=\left(\theta_{\mathrm{f}}-\theta_{\mathrm{w}}\right) \mathrm{Z}_{\mathrm{e}}$

where $Z_{\mathrm{e}}$ is effective root depth $(\mathrm{mm}), \theta_{\mathrm{f}}$ and $\theta_{\mathrm{w}}$ are, respectively, the field capacity and the wilting point soil water contents $\left(\mathrm{cm}^{3} \mathrm{~cm}^{-3}\right)$.
Using $i$ as an index to number the chosen period during the year (for the monthly case, $i=1,2, \ldots, 12$ ), we have:

$$
\text { If }\left(P_{i}-E T o_{i}\right)<0 \text { (case I - dry season): }
$$

$L_{i}=L_{i-1}-\left(P_{i}-E T o_{i}\right)$

and

$$
\begin{aligned}
A_{i}= & A_{C} \cdot \mathrm{e}^{-\frac{L_{i}}{A_{C}}} \\
& \text { If }\left(P_{i}-E T o_{i}\right) \geq 0 \text { (case II - wet season): } \\
A_{i}= & A_{i-1}+\left(P_{i}-E T o_{i}\right) ; \text { if } A_{i} \geq A_{C} \text { then } A_{i}=A_{C}
\end{aligned}
$$

and

$L_{i}=-A_{\mathrm{C}} \cdot \ln \left(\frac{A_{i}}{A_{\mathrm{C}}}\right)$

The actual evapotranspiration $\left(E T a_{i}, \mathrm{~mm}\right)$, for the period $i$, can be computed as follows:

$\Delta A_{i}=A_{i}-A_{i-1}$

$E T a_{i}=P_{i}+\Delta A_{i}$

where $\Delta A_{i}$ is the soil water storage change between the periods $i$ and $i-1$.

The soil water deficit $(D, \mathrm{~mm})$ and excess $(E, \mathrm{~mm})$ can be calculated as follows:

case I (dry season):

$D_{i}=E T o_{i}-E T a_{i}$

$E_{i}=0$

case II (wet season):

$D_{i}=0$

$E_{i}=P_{i}-E T o_{i}-\Delta A_{i}$

Procedures to estimate soil water storage at the end of the wet season

\section{Thornthwaite and Mather (1955)}

The soil water storage $A_{i}$ is assumed to be at its maximum value $A_{\mathrm{C}}$ (field capacity) at the end of the last month of the wet season. Hence, for this month corresponding to the last month of the wet season, $L_{i-1}=0$ (Figure 1). The iterative calculation procedure begins in month $i$, the first month of the dry season using equations (3) and (4), as schematically presented in Figure 1. In the case of arid and semi-arid conditions, for which field capacity is not even reached at the end of a wet season, this procedure applied iteratively until conver- 


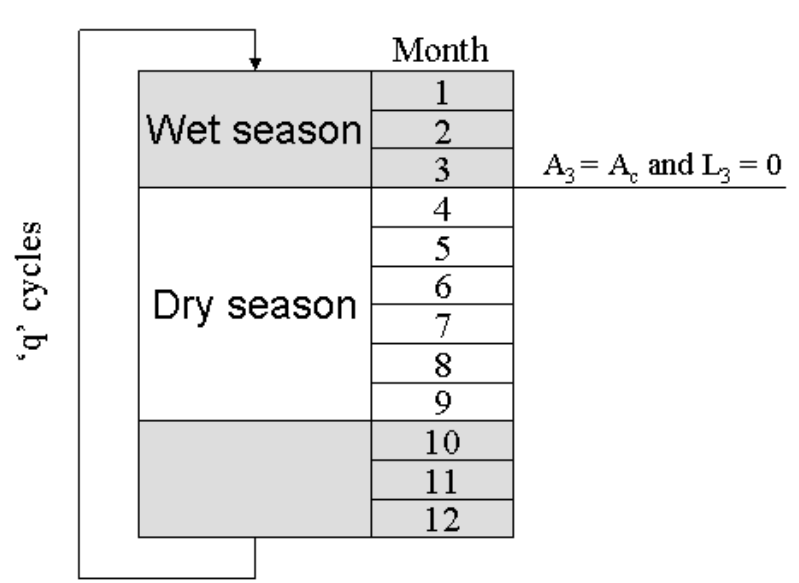

Figure 1 - A schematic example of the Thornthwaite and Mather's (1955) procedure to initialize the cyclic monthly soil water balance.

gence of the monthly values of soil water storage is reached leads to an inconvenient calculation routine.

\section{Mendonça (1958)}

To avoid the need of the iterative computing procedure described above for the case of a dry climate, Mendonça (1958) proposed a procedure (Figure 2) to initialize the cyclic monthly soil water balance for those cases in which one wetter season can be identified. Using the expressions:

$\alpha=\mathrm{e}^{-\lambda}$

with

$\alpha=\frac{A}{A_{\mathrm{C}}}$

$\lambda=\frac{L}{A_{\mathrm{C}}}$

A system of two equations and two unknown variables $x$ and $y$ (Figure 2) can be written based on equations (13), (14) and (15):

$y+p=\mathrm{e}^{-x}$ (end of wet season)

$y=\mathrm{e}^{-(x+n)}$ (end of dry season)

where $y$ is $A$ per unit of $A_{C}(y=\alpha)$ in last month of the dry season, $x$ is $L$ per unit of $A_{C}(\mathrm{x}=\lambda)$ in the last month of the wet season, and $L_{d}, L_{w}, n$ and $p$ are defined as:

$$
\begin{aligned}
& \mathrm{L}_{\mathrm{d}}=-\sum_{i=a}^{b}\left(\mathrm{P}_{\mathrm{i}}-\mathrm{ETo}_{\mathrm{i}}\right) ; \text { if }\left(P_{i}-E T o_{i}\right)<0 \text { and } b \geq a \\
& \mathrm{~L}_{\mathrm{d}}=-\sum_{i=a}^{12}\left(\mathrm{P}_{\mathrm{i}}-\mathrm{ETo}_{\mathrm{i}}\right)-\sum_{i=1}^{b}\left(\mathrm{P}_{\mathrm{i}}-\mathrm{ETo}_{\mathrm{i}}\right) ; \text { if }\left(\mathrm{P}_{\mathrm{i}}-\mathrm{ETo}_{\mathrm{i}}\right)<0
\end{aligned}
$$

and if $b<a$

$\mathrm{L}_{\mathrm{w}}=\sum_{i=b+1}^{12}\left(\mathrm{P}_{\mathrm{i}}-\mathrm{ETo}_{\mathrm{i}}\right)+\sum_{i=1}^{a-1}\left(\mathrm{P}_{\mathrm{i}}-\mathrm{ETo}_{\mathrm{i}}\right)$; if $\left(\mathrm{P}_{\mathrm{i}}-\mathrm{ETo}_{\mathrm{i}}\right) \geq 0$ and if $\mathrm{b} \geq \mathrm{a}$

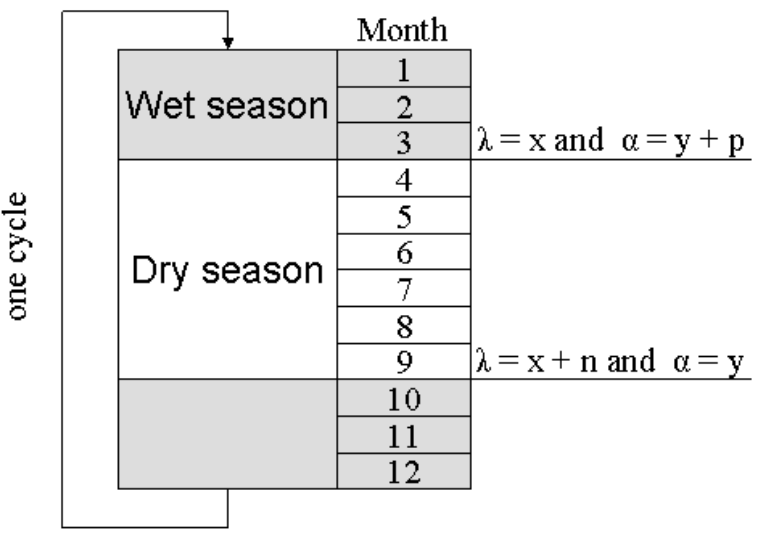

Figure 2 - A schematic example of the Mendonça (1958) procedure to initialize the cyclic monthly soil water balance for arid and semi-arid areas with just one wet season.

$\mathrm{L}_{\mathrm{w}}=\sum_{i=b+1}^{a-1}\left(\mathrm{P}_{\mathrm{i}}-\mathrm{ETo}_{\mathrm{i}}\right)$; if $\left(\mathrm{P}_{\mathrm{i}}-\mathrm{ETo}_{\mathrm{i}}\right) \geq 0$ and if $\mathrm{b}<\mathrm{a}$ :

$\mathrm{n}=\frac{\mathrm{L}_{\mathrm{d}}}{\mathrm{A}_{\mathrm{C}}}$

$\mathrm{p}=\frac{\mathrm{L}_{\mathrm{w}}}{\mathrm{A}_{\mathrm{C}}}$

where $a$ and $b$ are the numbers of order of the first and the last month of the dry season, respectively.

To estimate $L$ in the last month of the wet season of a cyclic monthly soil water balance, Mendonça (1958) proposed:

$L=-A_{C} \cdot \ln \left(\frac{p}{1-e^{-n}}\right)=-A_{C} \cdot x$

This equation allows $L$ to be obtained in a straightforward way whereas it would take several cycles to find $L$ by convergence using the original Thornthwaite and Mather procedure.

\section{The proposed procedure}

A general procedure is proposed analogous to the Mendonça procedure, but for cases where more than one dry and wet seasons can be identified, irrespective of the time step within the period considered for analysis. This approach becomes relevant especially when using daily or weekly time scales (calculation steps, input data). The general equation to define $L$ at the last period of the first wet season, in case of two (Figure 3) and three (Figure 4) dry and wet seasons, allowing the computation of soil water storage at the first period of the subsequent dry season are, respectively (Appendix B and C):

$L=-A_{\mathrm{C}} \cdot \ln \left[\frac{p_{1}+p_{2} \cdot e^{-n_{2}}}{1-e^{-\left(n_{1}+n_{2}\right)}}\right]$ (two dry seasons)

and

$L=-A_{\mathrm{C}} \cdot \ln \left[\frac{p_{1}+p_{2} \cdot e^{-\left(n_{2}+n_{3}\right)}+p_{3} \cdot e^{-n_{3}}}{1-e^{-\left(n_{1}+n_{2}+n_{3}\right)}}\right]$

(three dry seasons) 
For the case of $k$ dry seasons, the general equation to define $L$ at the last period of the first wet season (Figure 5) is:

$$
L=-A_{C} \cdot \ln \left(\frac{\mathrm{p}_{1}+\sum_{i=2}^{\mathrm{k}} p_{i} \cdot e^{-\sum_{j=i}^{k} n_{j}}}{1-\mathrm{e}^{-\sum_{i=1}^{k} \mathrm{n}_{\mathrm{i}}}}\right)(\mathrm{k} \geq 1)
$$

If $\mathrm{k}=1$, equation (25) reduces to equation (22) as proposed by Mendonça (1958) for just one dry season (Table 1).

\section{Results and Discussion}

The application of the Thornthwaite and Mather (1955) procedure to initialize the climatic cyclic soil water balance $(L=0 \mathrm{~mm})$ (Tables 2 and 4 , with one wet season in March; and Tables 3 and 5, with two wet sea-

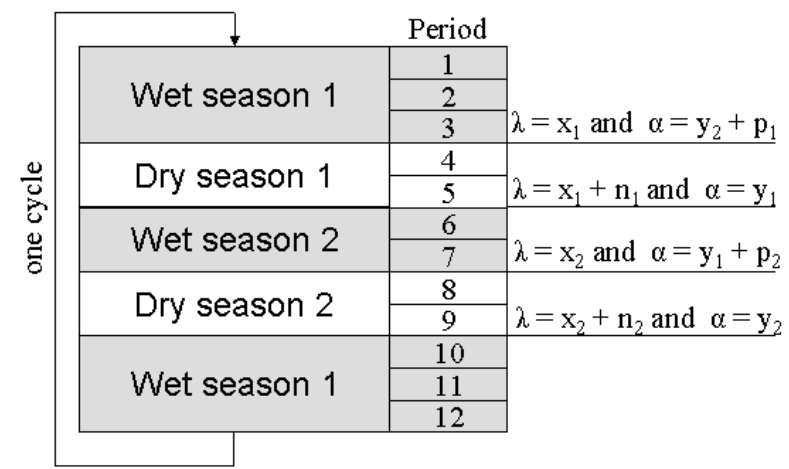

Figure 3 - A schematic example to illustrate the procedure of beginning the cyclic soil water balance, for arid and semi-arid areas, with two dry seasons. sons in February and November) for Petrolina (State of Pernambuco, Brazil), results in $\mathrm{L}=399.8460 \mathrm{~mm}$ and $\mathrm{L}=436.2771 \mathrm{~mm}$, respectively, after four $(\mathrm{q}=4)$ iterations (in both cases).

Using the Mendonça (1958) procedure (ME) (Table 1), for the case of a single dry period in Petrolina (Table 2 and 4 ), the accumulated potential water loss (L, $\mathrm{mm}$ ) at the end of the last month of the wet season is calculated directly using parameters shown in Table 6. Using the proposed procedure (PP) (Table 1, equation 25), the accumulated potential water loss $\left(L_{2}, \mathrm{~mm}\right)$ at the onset of the first dry season (February) is calculated directly (Table 7).

The Thornthwaite and Mather (1955) soil water balance method is popular in regions with low data availability. To apply this method in dry climates, an initial

\begin{tabular}{|c|c|c|}
\hline & Period & \multirow[b]{4}{*}{$\lambda=x_{1}$ and $\alpha=y_{3}+p_{1}$} \\
\hline \multirow{3}{*}{ Wet season 1} & 1 & \\
\hline & 2 & \\
\hline & 3 & \\
\hline \multirow{2}{*}{ Dry season 1} & 4 & \multirow[b]{2}{*}{$\lambda=\mathrm{x}_{1}+\mathrm{n}_{1}$ and $\alpha=\mathrm{y}_{1}$} \\
\hline & 5 & \\
\hline Wet season 2 & $\frac{6}{7}$ & $\lambda=x_{2}$ and $\alpha=y_{1}+p_{2}$ \\
\hline \multirow{2}{*}{ Dry season 2} & $\frac{7}{8}$ & \multirow[b]{2}{*}{$\lambda=\mathrm{x}_{2}+\mathrm{n}_{2}$ and $\alpha=\mathrm{y}_{2}$} \\
\hline & 9 & \\
\hline \multirow{3}{*}{ Wet season 3} & 10 & \multirow[b]{3}{*}{$\lambda=\mathrm{x}_{3}$ and $\alpha=\mathrm{y}_{2}+\mathrm{p}_{3}$} \\
\hline & 11 & \\
\hline & 12 & \\
\hline \multirow{3}{*}{ Dry season 3} & 13 & \multirow{5}{*}{$\lambda=\mathrm{x}_{3}+\mathrm{n}_{3}$ and $\alpha=\mathrm{y}_{3}$} \\
\hline & 14 & \\
\hline & 15 & \\
\hline \multirow{2}{*}{ Wet season 1} & 16 & \\
\hline & 17 & \\
\hline
\end{tabular}

Figure 4 - A schematic example to illustrate the procedure of beginning the cyclic soil water balance, for arid and semi-arid areas, with three dry seasons.

Table 1 - Procedures (Thornthwaite and Mather - TM, Mendonça - ME, and the proposed procedure - PP) to estimate initial parameters for a cyclic soil water balance based on the Thornthwaite and Mather (1955) method, defining the accumulated potential water loss $\mathrm{L}$ at the last period of the wet season.

\begin{tabular}{|c|c|c|c|c|}
\hline Procedure & Number of seasons & Equation for accumulated potential water loss & Equation \# & Figure \# \\
\hline $\mathrm{TM}$ & $k$ & $L=0$ & - & 1 \\
\hline ME & 1 & $L=-A_{C} \cdot \ln \left(\frac{p}{1-e^{-n}}\right)$ & 22 & 2 \\
\hline $\mathrm{PP}$ & 2 & $L=-A_{C} \cdot \ln \left[\frac{p_{1}+p_{2} \cdot e^{-n_{2}}}{1-e^{-\left(n_{1}+n_{2}\right)}}\right]$ & 23 & 3 \\
\hline $\mathrm{PP}$ & 3 & $L=-A_{C} \cdot \ln \left[\frac{p_{1}+p_{2} \cdot e^{-\left(n_{2}+n_{3}\right)}+p_{3} \cdot e^{-n_{3}}}{1-e^{-\left(n_{1}+n_{2}+n_{3}\right)}}\right]$ & 24 & 4 \\
\hline PP & $k$ & $L=-A_{c} \cdot \ln \left(\frac{p_{1}+\sum_{i=2}^{\mathrm{k}} p_{i} \cdot \exp \left(-\sum_{j=i}^{\mathrm{k}} n_{j}\right)}{1-\exp \left(-\sum_{i=1}^{\mathrm{k}} n_{i}\right)}\right.$ & 25 & 5 \\
\hline
\end{tabular}


Table 2 - The Thornthwaite and Mather procedure to initialize the climatic cyclic soil water balance (one wet season March). Petrolina-PE, Brazil (period: 1975 to 2006).

\begin{tabular}{|c|c|c|c|c|c|c|c|c|c|c|c|}
\hline \multirow{2}{*}{ Month } & \multirow{2}{*}{ P-ETO } & \multirow{2}{*}{$L$} & \multirow{2}{*}{$A$} & \multicolumn{2}{|c|}{ Iteration 1} & \multicolumn{2}{|c|}{ Iteration 2} & \multicolumn{2}{|c|}{ Iteration 3} & \multicolumn{2}{|c|}{ Iteration 4} \\
\hline & & & & $L$ & $A$ & $L$ & $A$ & $L$ & $A$ & $L$ & $A$ \\
\hline J & -70.9 & & & 921.3599 & 0.0787 & 1320.0009 & 0.0032 & 1321.2054 & 0.0032 & 1321.2059 & 0.0032 \\
\hline $\mathrm{F}$ & -52.9 & & & 974.2605 & 0.0515 & 1372.9014 & 0.0021 & 1374.1059 & 0.0021 & 1374.1064 & 0.0021 \\
\hline M & 5.1 & 0.0000 & 125.0000 & 398.6409 & 5.1510 & 399.8455 & 5.1016 & 399.8460 & 5.1016 & 399.8460 & 5.1016 \\
\hline A & -42.4 & 42.4423 & 89.0124 & 441.0832 & 3.6680 & 442.2878 & 3.6328 & 442.2883 & 3.6328 & & \\
\hline M & -78.8 & 121.2242 & 47.3952 & 519.8652 & 1.9531 & 521.0697 & 1.9343 & 521.0702 & 1.9343 & & \\
\hline $\mathrm{J}$ & -97.8 & 219.0062 & 21.6773 & 617.6471 & 0.8933 & 618.8516 & 0.8847 & 618.8521 & 0.8847 & & \\
\hline $\mathrm{J}$ & -94.8 & 313.7881 & 10.1554 & 712.4290 & 0.4185 & 713.6336 & 0.4145 & 713.6341 & 0.4145 & & \\
\hline A & -103.8 & 417.5700 & 4.4271 & 816.2110 & 0.1824 & 817.4155 & 0.1807 & 817.4160 & 0.1807 & & \\
\hline S & -118.4 & 536.0123 & 1.7164 & 934.6532 & 0.0707 & 935.8578 & 0.0700 & 935.8583 & 0.0700 & & \\
\hline $\mathrm{O}$ & -142.3 & 678.2856 & 0.5499 & 1076.9265 & 0.0227 & 1078.1310 & 0.0224 & 1078.1315 & 0.0224 & & \\
\hline $\mathrm{N}$ & -113.3 & 791.5588 & 0.2222 & 1190.1998 & 0.0092 & 1191.4043 & 0.0091 & 1191.4048 & 0.0091 & & \\
\hline $\mathrm{D}$ & -58.9 & 850.4594 & 0.1387 & 1249.1003 & 0.0057 & 1250.3048 & 0.0057 & 1250.3053 & 0.0057 & & \\
\hline$\Delta \mathrm{L}_{3}$ & & & & -398.6409 & & -1.2045 & & -0.0005 & & 0.0000 & \\
\hline
\end{tabular}

$E T_{0}$ : reference evapotranspiration $(\mathrm{mm}) ; P$ : pluvial precipitation $(\mathrm{mm}) ; L$ : accumulated potential water loss $(\mathrm{mm}) ; A$ : soil water storage $(\mathrm{mm}) ; A \mathrm{c}=125 \mathrm{~mm}$ (soil water holding capacity).

Table 3 - The Thornthwaite and Mather procedure to initialize the climatic cyclic water balance (two wet seasons February and November). Petrolina-PE, Brazil (year: 1976).

\begin{tabular}{|c|c|c|c|c|c|c|c|c|c|c|c|}
\hline \multirow{2}{*}{ Month } & \multirow{2}{*}{$P-E T 0_{0}$} & \multirow{2}{*}{$L$} & \multirow{2}{*}{$A$} & \multicolumn{2}{|c|}{ Iteration 1} & \multicolumn{2}{|c|}{ Iteration 2} & \multicolumn{2}{|c|}{ Iteration 3} & \multicolumn{2}{|c|}{ Iteration 4} \\
\hline & & & & $L$ & $A$ & $L$ & $A$ & $L$ & $A$ & $L$ & $A$ \\
\hline $\mathrm{J}$ & -124.8 & & & 656.6815 & 0.6537 & 660.8464 & 0.6323 & 660.8472 & 0.6323 & 660.8472 & 0.6323 \\
\hline $\mathrm{E}$ & 3.2 & 0.0000 & 125.0000 & 435.5765 & 3.8332 & 436.2770 & 3.8118 & 436.2771 & 3.8118 & 436.2771 & 3.8118 \\
\hline M & -113.4 & 113.3924 & 50.4597 & 548.9689 & 1.5474 & 549.6694 & 1.5387 & 549.6695 & 1.5387 & & \\
\hline A & -112.2 & 225.6381 & 20.5571 & 661.2147 & 0.6304 & 661.9152 & 0.6269 & 661.9153 & 0.6269 & & \\
\hline M & -124.5 & 350.1839 & 7.5901 & 785.7604 & 0.2328 & 786.4609 & 0.2315 & 786.4610 & 0.2315 & & \\
\hline $\mathrm{J}$ & -100.3 & 450.4395 & 3.4035 & 886.0160 & 0.1044 & 886.7165 & 0.1038 & 886.7166 & 0.1038 & & \\
\hline J & -86.2 & 536.6592 & 1.7075 & 972.2358 & 0.0524 & 972.9363 & 0.0521 & 972.9364 & 0.0521 & & \\
\hline A & -96.9 & 633.5920 & 0.7863 & 1069.1685 & 0.0241 & 1069.8690 & 0.0240 & 1069.8691 & 0.0240 & & \\
\hline S & -108.6 & 742.2027 & 0.3298 & 1177.7792 & 0.0101 & 1178.4797 & 0.0101 & 1178.4799 & 0.0101 & & \\
\hline $\mathrm{O}$ & -73.3 & 815.5171 & 0.1834 & 1251.0936 & 0.0056 & 1251.7941 & 0.0056 & 1251.7942 & 0.0056 & & \\
\hline $\mathbf{N}$ & 5.2 & 392.1310 & 5.4263 & 396.2959 & 5.2485 & 396.2967 & 5.2485 & $\underline{396.2967}$ & 5.2485 & & \\
\hline $\mathrm{D}$ & -139.7 & 531.8662 & 1.7743 & 536.0311 & 1.7161 & 536.0318 & 1.7161 & 536.0318 & 1.7161 & & \\
\hline$\Delta \mathrm{L}_{2}$ & & & & -435.5765 & & -0.7005 & & -0.0001 & & 0.0000 & \\
\hline$\Delta \mathrm{L}_{11}$ & & & & -4.1649 & & -0.0007 & & 0.0000 & & & \\
\hline
\end{tabular}

$E T$ : reference evapotranspiration $(\mathrm{mm}) ; P$ : pluvial precipitation $(\mathrm{mm}) ; L$ : accumulated potential water loss (mm); $A$ : soil water storage $(\mathrm{mm}) ; A \mathrm{c}=125 \mathrm{~mm}$ (soil water holding capacity).

accumulated potential water loss must be estimated which, according to Thornthwaite and Mather (1955) can be done in an iterative procedure. As this iterative method is quite cumbersome, we propose a straightforward calculation procedure to calculate this initial accumulated potential water loss; a similar equation had already been proposed by Mendonça (1958), but unlike his equation, the one we deduced allows to express the water storage for the case of the occurrence of more than one dry seasons per year, a situation which becomes especially relevant when the soil water balance is estimated at a daily scale in arid and semi-arid climates. The procedure is meant to substitute for the originally proposed iterative routine. An example of application shows a perfect agreement between the proposed procedure and the original (iterative) procedure. 
Table 4 - Climatic cyclic water balance (one dry season - March) using the Thornthwaite and Mather method. PetrolinaPE, Brazil (period: 1975 to 2006).

\begin{tabular}{lccccccccc}
\hline Month & $T$ & $E T o$ & $P$ & $L$ & $A$ & $\Delta A$ & $E T_{\mathrm{a}}$ & \multicolumn{1}{c}{$D$} & $E$ \\
\hline J & 27 & 142.9 & 72 & 1321.2059 & 0.0032 & 0.0 & 72.0 & 70.9 & 0.0 \\
F & 27 & 142.9 & 90 & 1374.1064 & 0.0021 & 0.0 & 90.0 & 52.9 & 0.0 \\
M & 27 & 142.9 & 148 & $\mathbf{3 9 9 . 8 4 6 0}$ & 5.1016 & 5.1 & 142.9 & 0.0 & 0.0 \\
A & 26 & 124.4 & 82 & 442.2883 & 3.6328 & -1.5 & 83.5 & 41.0 & 0.0 \\
M & 25 & 107.8 & 29 & 521.0702 & 1.9343 & -1.7 & 30.7 & 77.1 & 0.0 \\
J & 25 & 107.8 & 10 & 618.8521 & 0.8847 & -1.0 & 11.0 & 96.7 & 0.0 \\
J & 25 & 107.8 & 13 & 713.6341 & 0.4145 & -0.5 & 13.5 & 94.3 & 0.0 \\
A & 25 & 107.8 & 4 & 817.4160 & 0.1807 & -0.2 & 4.2 & 103.5 & 0.0 \\
S & 26 & 124.4 & 6 & 935.8583 & 0.0700 & -0.1 & 6.1 & 118.3 & 0.0 \\
O & 28 & 163.3 & 21 & 1078.1315 & 0.0224 & 0.0 & 21.0 & 142.2 & 0.0 \\
N & 28 & 163.3 & 50 & 1191.4048 & 0.0091 & 0.0 & 50.0 & 113.3 & 0.0 \\
D & 27 & 142.9 & 84 & 1250.3053 & 0.0057 & 0.0 & 84.0 & 58.9 & 0.0 \\
\hline Total & 26.3 & $1,578.2$ & 609.0 & & & & 609.0 & 969.2 & 0.0 \\
\hline
\end{tabular}

$T$ : air temperature $\left({ }^{\circ} \mathrm{C}\right) ; E T$ : reference evapotranspiration $(\mathrm{mm}) ; P$ : pluvial precipitation $(\mathrm{mm}) ; L$ : accumulated potential water loss $(\mathrm{mm}) ; A$ : soil water storage $(\mathrm{mm}) ; \Delta A$ : soil water storage change $(\mathrm{mm}) ; E T$ : actual evapotranspiration $(\mathrm{mm}) ; D$ : water deficit $(\mathrm{mm}) ;$ $E$ : water excess $(\mathrm{mm}) ; A_{\mathrm{c}}=125 \mathrm{~mm}$ (soil water holding capacity).

*http://www.theweathernetwork.com/index.php?product = statistics\&pagecontent $=$ C03198.

Table 5 - Climatic cyclic water balance (two dry seasons) using the Thornthwaite and Mather method. Petrolina-PE, Brazil (year: 1976).

\begin{tabular}{lccccccrrr}
\hline Month & $T$ & $E T o$ & $P$ & $L$ & $A$ & \multicolumn{1}{c}{$\Delta A$} & $E T_{a}$ & \multicolumn{1}{c}{$D$} \\
\hline J & 27 & 143.5 & 19 & 660.8472 & 0.6323 & -1.1 & 19.8 & 123.7 & 0.0 \\
F & 25 & 107.4 & 111 & $\mathbf{4 3 6 . 2 7 7 1}$ & 3.8118 & 3.2 & 107.4 & 0.0 & 0.0 \\
M & 26 & 126.2 & 13 & 549.6695 & 1.5387 & -2.3 & 15.1 & 111.1 & 0.0 \\
A & 26 & 124.5 & 12 & 661.9153 & 0.6269 & -0.9 & 13.2 & 111.3 & 0.0 \\
M & 26 & 124.5 & 0 & 786.4610 & 0.2315 & -0.4 & 0.4 & 124.2 & 0.0 \\
J & 25 & 103.1 & 3 & 886.7166 & 0.1038 & -0.1 & 2.9 & 100.1 & 0.0 \\
J & 23 & 88.1 & 2 & 972.9364 & 0.0521 & -0.1 & 2.0 & 86.2 & 0.0 \\
A & 24 & 97.4 & 1 & 1069.8691 & 0.0240 & 0.0 & 0.5 & 96.9 & 0.0 \\
S & 26 & 118.1 & 10 & 1178.4799 & 0.0101 & 0.0 & 9.5 & 108.6 & 0.0 \\
O & 26 & 122.9 & 50 & 1251.7942 & 0.0056 & 0.0 & 49.6 & 73.3 & 0.0 \\
N & 27 & 134.7 & 140 & $\mathbf{3 9 6 . 2 9 6 7}$ & 5.2485 & 5.2 & 134.7 & 0.0 & 0.0 \\
D & 27 & 145.3 & 6 & 536.0318 & 1.7161 & -3.5 & 9.1 & 136.2 & 0.0 \\
\hline Total & 25.5 & $1,435.8$ & 364.2 & & & & 364.2 & $1,071.6$ & 0.0 \\
\hline
\end{tabular}

$T$ : air temperature $\left({ }^{\circ} \mathrm{C}\right) ; E T$ : reference evapotranspiration $(\mathrm{mm}) ; P$ : pluvial precipitation $(\mathrm{mm}) ; L$ : accumulated potential water loss $(\mathrm{mm}) ; A$ : soil water storage $(\mathrm{mm}) ; \Delta A$ : soil water storage change $(\mathrm{mm}) ; E T_{\mathrm{a}}$ : actual evapotranspiration $(\mathrm{mm}) ; D$ : water deficit $(\mathrm{mm})$; $E:$ water excess $(\mathrm{mm}) ; A_{\mathrm{c}}=125 \mathrm{~mm}$ (soil water holding capacity).

*http://www.theweathernetwork.com/index.php?product $=$ statistics\&pagecontent $=$ C03198.

Table 6 - Values of the auxiliary parameters $\left(L_{d}, L_{w}, n, p\right.$ and $\left.x\right)$, the accumulated potential water loss in March $\left(L_{3}, \mathrm{~mm}\right)$, for one wet season $(k=1)$, using Mendonça’s procedure (Table 4). Petrolina-PE, Brazil (period: 1975 to 2006).

\begin{tabular}{lccccc}
\hline$L_{d}(\mathrm{~mm})$ & $L_{w}(\mathrm{~mm})$ & $n$ & $p$ & $x$ & $L_{3}(\mathrm{~mm})$ \\
\hline 974.2605 & 5.0995 & 7.7941 & 0.0408 & 3.1988 & 399.8460 \\
\hline
\end{tabular}

$n$ : accumulated potential water loss during the dry season $\left(L_{d}, \mathrm{~mm}\right)$ per unit of soil water holding capacity $(A c, \mathrm{~mm})(\mathrm{equation} 20)$. $p$ : accumulated potential water loss during the wet season $\left(L_{w}, \mathrm{~mm}\right)$ per unit of soil water holding capacity $(A c, \mathrm{~mm})($ equation 21$)$. $x$ : accumulated potential water loss at the last period of the wet season $\left(L_{3}, \mathrm{~mm}\right)$ per unit of soil water holding capacity $\left(A_{\mathrm{c}}=125 \mathrm{~mm}\right)$ (equation 22). 
Table 7 - Values of the auxiliary parameters $\left(L d_{1}, L d_{2}, L w_{1}, L w_{2}, n_{1}, n_{2}, p_{1}, p_{2}, x_{1}\right.$ and $\left.x_{2}\right)$, the accumulated potential water losses in February and November $\left(L_{2}\right.$ and $\left.L_{11}, \mathrm{~mm}\right)$, for two wet seasons $(k=2)$, using the proposed procedure (Table 5). Petrolina-PE, Brazil (year: 1976).

\begin{tabular}{lccccc}
\hline$L d_{1}(\mathrm{~mm})$ & $L w_{1}(\mathrm{~mm})$ & $n_{1}$ & $p_{1}$ & $x_{1}$ & $L_{2}(\mathrm{~mm})$ \\
\hline 815.5171 & 3.1795 & 6.5241 & 0.0254 & 3.4902 & 436.2771 \\
\hline$L d_{2}(\mathrm{~mm})$ & $L w_{2}(\mathrm{~mm})$ & $n_{2}$ & $p_{2}$ & $x_{2}$ & $L_{11}(\mathrm{~mm})$ \\
\hline 264.5505 & 5.2429 & 2.1164 & 0.0419 & 3.1704 & 396.2967 \\
\hline
\end{tabular}

$n_{1}$ and $n_{2}$ : accumulated potential water loss during the first and second dry seasons ( $L d_{1}$ and $\left.L d_{2}, \mathrm{~mm}\right)$ per unit of soil water holding capacity $(A c, \mathrm{~mm})$ (equation 20$) \cdot p_{1}$ and $p_{2}$ : accumulated potential water loss during the first and second wet seasons $\left(L w_{1}\right.$ and $\left.L w_{2}, \mathrm{~mm}\right)$ per unit of soil water holding capacity $(A c, \mathrm{~mm})$ (equation 21). $x_{1}$ and $x_{2}$ : accumulated potential water loss at the last period of the first and second wet seasons $\left(L_{2}\right.$ and $\left.L_{1}, \mathrm{~mm}\right)$ per unit of soil water holding capacity $\left(A_{\mathrm{c}}=125 \mathrm{~mm}\right)$ (equation 23).

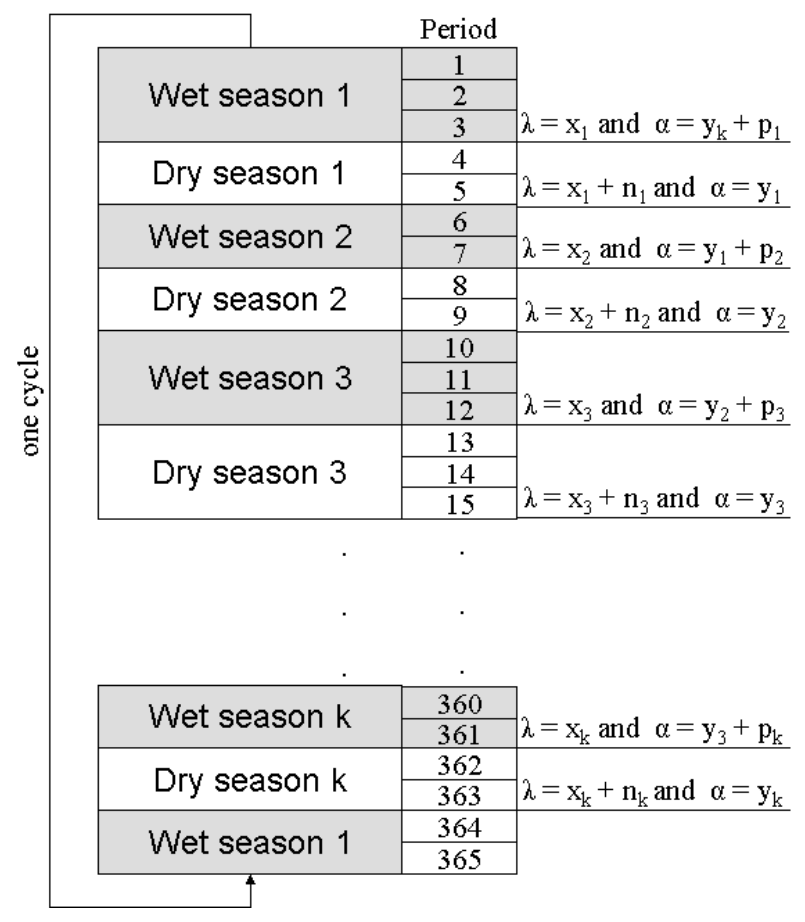

Figure 5 - A schematic example to illustrate the procedure of beginning the cyclic soil water balance, for arid and semi-arid areas, with $k$ dry seasons.

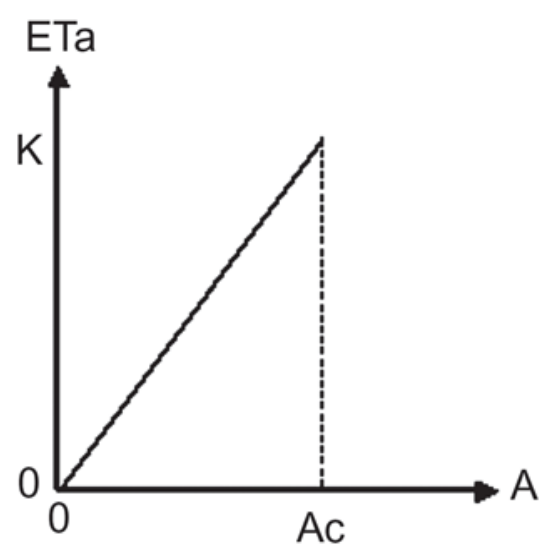

Figure 6 - Hypothetical relationship between ETa and A (Thornthwaite and Mather, 1955).

\section{References}

Alley, W.M. 1984. On the treatment of evapotranspiration, soil moisture accounting, and aquifer recharge in monthly water balance models. Water Resources Research 20: 1137-1149.

Black, P.E. 1996. Watershed Hydrology. 2ed. CRC Press, Boca Raton, FL, USA. 408p.

Bruno, I.P.; Silva, A.L.; Reichardt, K.; Dourado-Neto, D.; Bacchi, O.O.S.; Volpe, C.A. 2007. Comparison between climatological and field water balances for a coffee crop. Scientia Agricola 64: 215-220.

Dunne, T.; Leopold, L.B. 1970. Water in Environmental Planning. W.H. Freeman, San Francisco, CA, USA. 818p.

Eaton, T.T. 1995. Estimating groundwater recharge using a modified soil-water budget method. In: Proceedings of AWRA. Wisconsin Nineteenth Annual Conference AWRA, Middleburg, VA, USA, p.18.

Howard, K.W.F; Lloyd, J.W. 1979. The sensitivity of parameters in the Penman evaporation equations and direct recharge balance. Journal of Hydrology 41: 329-344.

Krohelski, J.T.; Bradbury, K.R.; Hunt, R.J.; Swanson, S.K. 2000. Numerical simulation of groundwater flow in Dane County, Wisconsin. Wisconsin Geological and Natural History Survey, Madison, WI, USA, p.31. (Bulletin 98).

Martin, T.N.; Dourado-Neto, D.; Storck, L.; Burael, P.; Santos, E.A. 2008. Regiões homogêneas e tamanho de amostra para atributos do clima no estado de São Paulo, Brasil. Ciência Rural 38: 690-697.

Mendonça, P.V.E. 1958. Sobre o novo método de balance hídrico de Thornthwaite e Mather. In: Congresso Luso-Espanhol Para El Progresso De Las Ciencias 24, [sn], Madrid, Spain. p.415-425.

Rushton, K.R.; Eilers, V.H.M.; Carter, R.C. 2006. Improved soil moisture balance methodology for recharge estimation. Journal of Hydrology 318: 379-399.

Rushton, K.R.; Ward, C. 1979. The estimation of groundwater recharge. Journal of Hydrology 41: 345-361.

Silva, A.L.; Roveratti, R.; Reichardt, K.; Bacchi, O.O.S.; Timm, L.C.; Bruno, I.P.; Oliveira, J.C.M.; Dourado-Neto, D. 2006. Variability of Water Balance Components in a Coffee Crop Grown in Brazil. Scientia Agricola 63: 105-114.

Sparovek, G.; Jong Van Lier, Q.; Dourado-Neto, D. 2007. Computer assisted Köppen climate classification for Brazil. International Journal of Climatology 27: 257-266.

Steenhuis, T.; Van der Molen, W. 1986. The Thornthwaite-Mather procedure as a simple engineering method to predict recharge. Journal of Hydrology 84: 221-229.

Swanson, S.K. 1996. A comparison of two methods used to estimate groundwater recharge in Dane County, Wisconsin. M.Sc. Dissertation. University of Wisconsin, Madison, WI, USA.

Thornthwaite, C.W.; Mather, J.R. 1957. Instructions and tables for computing potential evapotranspiration and the water balance. Publication in Climatology 10: 185-311. 
Thornthwaite, C.W.; Mather, Jr. 1955. The Water Balance. Laboratory of Climatology, Centerton, NJ, USA.

\section{Appendix A}

The derivation of the basic equation of estimating the soil water storage

The Thornthwaite and Mather (1955) method is based on the following assumption (Figure 6):

$\frac{d B}{d t}=K \cdot \frac{A}{A_{C}}$

where

$K=E T o=\frac{L}{T}$

$A=A_{C}-B$

where $\mathrm{L}$ and $\mathrm{B}$ stand for the accumulated potential water loss (mm).

Substituting [A2] and [A3] in [A1] and rewriting in convenient form:

$\int_{0}^{L} \frac{1}{A_{C}-B} d B=\frac{L}{T \cdot A_{C}} \int_{0}^{T} d t$

The integral solution becomes:

$\left[-\left.\ln \left(\frac{1}{A_{C}-B}\right)\right|_{0} ^{L}\right]=\frac{L}{T \cdot A_{C}}\left(\left.t\right|_{0} ^{T}\right)$

Then

$A=A_{C} e^{-\frac{L}{A_{C}}}$

\section{Appendix B}

The proposed procedure for two dry and wet seasons

Applying equation (13) for the two dry and wet seasons case:

$y_{2}+p_{1}=e^{-x_{1}}$

$y_{1}=e^{-\left(x_{1}+n_{1}\right)}$

$y_{1}+p_{2}=e^{-x_{2}}$

$y_{2}=e^{-\left(x_{2}+n_{2}\right)}$ (B4):

Combining the equations (B1) and (B2) and (B3) and

$p_{1}=e^{-x_{1}}-e^{-\left(x_{2}+n_{2}\right)}$

$p_{2}=e^{-x_{2}}-e^{-\left(x_{1}+n_{1}\right)}$ forms:

Rewriting the equations (B5) and (B6) in convenient

$e^{-x_{1}}-e^{-n_{2}} \cdot e^{-x_{2}}=p_{1}$

$-e^{-n_{1}} \cdot e^{-x_{1}}+e^{-x_{2}}=p_{2}$

Then, by Kramer's rule:
$D p=\left|\begin{array}{cc}1 & -e^{-n_{2}} \\ -e^{-n_{1}} & 1\end{array}\right|=1-e^{-\left(n_{1}+n_{2}\right)}$

$D_{1}=\left|\begin{array}{cc}p_{1} & -e^{-n_{2}} \\ p_{2} & 1\end{array}\right|=p_{1}+p_{2} \cdot e^{-n_{2}}$

$D_{2}=\left|\begin{array}{cc}1 & p_{1} \\ -e^{-n_{1}} & p_{2}\end{array}\right|=p_{2}+p_{1} \cdot e^{-n_{1}}$

$e^{-x_{1}}=\frac{D_{1}}{D p}=\frac{p_{1}+p_{2} \cdot e^{-n_{2}}}{1-e^{-\left(n_{1}+n_{2}\right)}}$

$e^{-x_{2}}=\frac{D_{2}}{D p}=\frac{p_{2}+p_{1} \cdot e^{-n_{1}}}{1-e^{-\left(n_{1}+n_{2}\right)}}$

$x_{1}=-\ln \left[\frac{p_{1}+p_{2} \cdot e^{-n_{2}}}{1-e^{-\left(n_{1}+n_{2}\right)}}\right]$ (cf. eq. 22)

$x_{2}=-\ln \left[\frac{p_{2}+p_{1} \cdot e^{-n_{1}}}{1-e^{-\left(n_{1}+n_{2}\right)}}\right]$

\section{Appendix C}

The proposed procedure for three dry and wet seasons Applying equation (13) for the three dry and wet seasons case:

$y_{3}+p_{1}=e^{-x_{1}}$

$y_{1}=e^{-\left(x_{1}+n_{1}\right)}$

$y_{1}+p_{2}=e^{-x_{2}}$

$y_{2}=e^{-\left(x_{2}+n_{2}\right)}$

$y_{2}+p_{3}=e^{-x_{3}}$

$y_{3}=e^{-\left(x_{3}+n_{3}\right)}$

Combining the equations [C1] and [C2], [C3] and [C4] and [C5] and [C6]:

$p_{1}=e^{-x_{1}}-e^{-\left(x_{3}+n_{3}\right)}$

$p_{2}=e^{-x_{2}}-e^{-\left(x_{1}+n_{1}\right)}$

$p_{3}=e^{-x_{3}}-e^{-\left(x_{2}+n_{2}\right)}$

Rewriting the equations [C7], [C8] and [C9] in convenient forms:

$e^{-x_{1}}-e^{-n_{3}} \cdot e^{-x_{3}}=p_{1}$

$-e^{-n_{1}} \cdot e^{-x_{1}}+e^{-x_{2}}=p_{2}$

$-e^{-n_{2}} \cdot e^{-x_{2}}+e^{-x_{3}}=p_{3}$

Then, by Kramer's rule:

$D p=\left|\begin{array}{ccc}1 & 0 & -e^{-n_{3}} \\ -e^{-n_{1}} & 1 & 0 \\ 0 & -e^{-n_{2}} & 1\end{array}\right|=1-e^{-\left(n_{1}+n_{2}+n_{3}\right)}$

Sci. Agric. (Piracicaba, Braz.), v.67, n.1, p.87-95, January/February 2010 
$\begin{aligned} D_{1} & =\left|\begin{array}{ccc}p_{1} & 0 & -e^{-n_{3}} \\ p_{2} & 1 & 0 \\ p_{3} & -e^{-n_{2}} & 1\end{array}\right|=p_{1}+p_{2} \cdot e^{-\left(n_{2}+n_{3}\right)}+p_{3} \cdot e^{-n_{3}}[\mathrm{C} 14] \\ D_{2} & =\left|\begin{array}{ccc}1 & p_{1} & -e^{-n_{3}} \\ -e^{-n_{1}} & p_{2} & 0 \\ 0 & p_{3} & 1\end{array}\right|=p_{2}+p_{3} \cdot e^{-\left(n_{1}+n_{3}\right)}+p_{1} \cdot e^{-n_{1}}[\mathrm{C} 15] \\ D_{3} & =\left|\begin{array}{ccc}1 & 0 & p_{1} \\ -e^{-n_{1}} & 1 & p_{2} \\ 0 & -e^{-n_{2}} & p_{3}\end{array}\right|=p_{3}+p_{1} \cdot e^{-\left(n_{1}+n_{2}\right)}+p_{2} \cdot e^{-n_{2}}[\mathrm{C} 16] \\ e^{-x_{1}} & =\frac{D_{1}}{D p}=\frac{p_{1}+p_{2} \cdot e^{-\left(n_{2}+n_{3}\right)}+p_{3} \cdot e^{-n_{3}}}{1-e^{-\left(n_{1}+n_{2}+n_{3}\right)}}\end{aligned}$

$e^{-x_{2}}=\frac{D_{2}}{D p}=\frac{p_{1} \cdot e^{-n_{1}}+p_{2}+p_{3} \cdot e^{-\left(n_{1}+n_{3}\right)}}{1-e^{-\left(n_{1}+n_{2}+n_{3}\right)}}$

$e^{-x_{3}}=\frac{D_{3}}{D p}=\frac{p_{1} \cdot e^{-\left(n_{1}+n_{2}\right)}+p_{2} \cdot e^{-n_{2}}+p_{3}}{1-e^{-\left(n_{1}+n_{2}+n_{3}\right)}}$

and

$x_{1}=-\ln \left[\frac{p_{1}+p_{2} \cdot e^{-\left(n_{2}+n_{3}\right)}+p_{3} \cdot e^{-n_{3}}}{1-e^{-\left(n_{1}+n_{2}+n_{3}\right)}}\right]$ (cf. eq. 23)

$x_{2}=-\ln \left[\frac{p_{1} \cdot e^{-n_{1}}+p_{2}+p_{3} \cdot e^{-\left(n_{1}+n_{3}\right)}}{1-e^{-\left(n_{1}+n_{2}+n_{3}\right)}}\right]$

$x_{3}=-\ln \left(\frac{p_{1} \cdot e^{-\left(n_{1}+n_{2}\right)}+p_{2} \cdot e^{-n_{2}}+p_{3}}{1-e^{-\left(n_{1}+n_{2}+n_{3}\right)}}\right)$ 